\title{
ANALISA KEPUASAN PELAYANAN PENGGUNA JASA APLIKASI GO-CAR MENGGUNAKAN METODE FUZZY SERVQUAL
}

\author{
Nandang Iriadi ${ }^{1}$ \\ Fakultas Teknologi Informasi, \\ Universitas Bina Sarana \\ Informatika \\ Email:_nandang.ndi@bsi.ac.id
}

\author{
Priatno $^{2}$ \\ Fakultas Komunikasi \& Bahasa \\ Universitas Bina Sarana \\ Informatika \\ Email:Priatno.prn@bsi.ac.id $\stackrel{2}{=}$
}

\author{
Mohammad Ikhsan Saputro ${ }^{3}$ \\ Fakultas Komputer Univeristas \\ MH Thamrin Jakarta \\ Email \\ ikhsansaputro@thamrin.ac.id ${ }^{3}$
}

\begin{abstract}
Abstrak-Modernisasi dalam ilmu sosial merujuk pada bentuk transformasi yakni dari keadaan yang kurang maju atau kurang berkembang ke arah yang lebih berkembang. Modernisasi mencakup banyak bidang, seperti dalam bidang ilmu pengetahuan dan teknologi. Tingginya kemaujan teknologi saat ini, memudahkan masyarakat berpergian dengan waktu yang lebih efisien. Beragam jenis transportasi online menghiasi Ibu Kota DKI Jakarta, mulai dari harga terendah hingga tertinggi. Penelitian ini memilih transportasi online yang ada di GO-JEK, yaitu GO-CAR sebagai objek penelitian. GO-CAR saat ini merupakan salah satu transportasi online yang sedang booming dikalangan masyarakat Jakarta dan luar Jakarta. Aplikasi GO-CAR dapat membantu masyarakat jika ingin menuju ke lokasi yang mengharuskan melewati jalan tol dan pada saat hujan jika ingin berpergian ke suatu tempat. Disamping kemudahan yang ditawarkan oleh GO-CAR bagi masyarakat, kualitas pelayanan GO-CAR patut untuk dipertanyakan baik dari segi pengemudi maupun pemesanan melalui aplikasi. Dalam penelitian ini menggunakan metode fuzzy servqual sebagai teori untuk mengetahui tingkat kepuasan masyarakat terhadap pelayanan GO-CAR. Hasil penelitian dengan menggunakan metode fuzzy servqual bahwa masyarakat yang menggunakan layanan GO-CAR merasa senang dan puas dengan jasa yang diberikan oleh pihak GOCAR. Masyarakat juga tidak memiliki kendala saat melakukan pemesaanan GO-CAR melalui aplikasi.
\end{abstract}

Kata Kunci: Metode Fuzzy, Metode Servaqual, Pengujian Rehabilitas

\section{PENDAHULUAN}

Dalam penelitian ini penulis akan memilih transportasi online yang dikeluarkan oleh perusahaan GO-JEK, yaitu GO-CAR sebagai objek penelitian. Alasan penulis memilih transportasi online GO-CAR, karena GO-CAR saat ini merupakan salah satu transportasi online yang sedang booming dikalangan masyarakat Jakarta dan luar Jakarta. Akan tetapi, disamping ketenarannya GO-CAR sendiri memiliki kendala dalam hal melayani konsumen. Menurut Resihono (2011) Pelayanan merupakan salah satu bentuk jasa yang ditawarkan kepada konsumen. Jasa adalah sesuatu kata yang diidentifikasikan secara terpisah berwujud, ditawarkan untuk memenuhi kebutuhan.

Menurut Parasuraman dalam Resihono (2011) ada lima karakteristik yang digunakan untuk mengevaluasi kualitas pelayanan jasa.

Adapun indikator variabel kualitas pelayanan jasa adalah:

1. Responsiveness (daya tanggap) adalah suatu respon atau kesigapan karyawan dalam membantu konsumen dan memberikan pelayanan yangcepat dan tanggap.

2. Reliability (kehandalan) adalah suatu kemampuan untuk memberikan jasa yang dijanjikan dengan akurat dan terpecaya.

3. Assurance (jaminan) adalah kemampuan karyawan atas pengetahuan terhadap produk secara tepat, kualitas, keramahtamahan, perkataan atau kesopanan dalam memberikan pelayanan, keterampilan dalam memberikan informasi dan kemampuan dalam menanamkan keparcayaan konsumen terhadap perusahaan.

4. Emphaty (perhatian) adalah kemampuan perusahaan dalam memberikan perhatian yang bersifat individual atau pribadi kepada para konsumen.

5. Tangibles (kemampuan fisik) adalah suatu bentuk penampilan fisik, peralatan personal, media komunikasi dan hal-hal yang lainnya yang bersifat fisik.

Menurut Tjiptono dalam Resihono (2014) Kepuasan konsumenmerupakan evaluasi purna 
beli dimana alternatif yang dipilih sekurangkurangnya memberi hasil sama atau melampaui harapan konsumen, sedangkan ketidakpuasan timbul apabila hasil yang diperoleh tidak memenuhi harapan konsumen.

Menurut Kusumadewi dan Purnomo (2013:) Logika fuzzy merupakan salah satu komponen pembentuk soft computing.Logika fuzzy pertama kali diperkenalkan oleh Prof. Lotfi A. Zadeh pada tahun 1965. Dasar logika fuzzy adalah teori himpunan fuzzy. Pada teori himpunan fuzzy, peranan derajat keanggotaan sebagai penentu keberadaan himpunan sangatlah penting. Nilai keanggotaan atau derajat keanggotaan atau membership function menjadi ciri utama dari penalaran dengan logika fuzzy tersebut. Menurut Sikumbang (2017) metode servqual merupakan metode yang digunakan untuk mengetahui kriteria-kriteria kualitas yang harus ditingkatkan kualitas pelayanannya berdasarkan gap yang terjadi antara persepsi dan harapan pelanggan.

Menurut Suparman dan Dahlan (2015:34) menjelaskan langkah-langkah yang perlu dilakukan pada metode servqual adalah sebagai berikut:

a. Tentukan rata-rata nilai kinerja atau persepsi (y) untuk setiap variabel.

$\bar{y}=$ Lyin

Keterangan:

$\bar{y}=$ Nilai rata-rata kinerja atau persepsi pelanggan

$\Sigma y i=$ Jumlah bobot jawaban responden

$n=$ Jumlah responden

b. Tentukan rata-rata nilai harapan atau ekspetasi (x) untuk setiap variabel.

$n=\Sigma x i n$

Keterangan:

$\bar{x}=$ Nilai rata-rata harapan atau ekpetasi pelanggan

$\Sigma x i=$ Jumlah bobot jawaban responden

$n=$ Jumlah reponden

c. Tentukan Servqual score (S) untuk setiap variabel.

$\mathrm{SQ}=\bar{y}-\bar{x}$

Keterangan:

$\mathrm{SQ}=$ Nilai gap

$\bar{y}=$ Nilai rata-rata Kinerja atau persepsi pelanggan

$\bar{x}=$ Nilai rata-rata harapan atau ekspetasi pelanggan

Menurut Sugiyono (2010) "Populasi adalah wilayah generalisasi yang terdiri atas: Obyek atau subyek yang mempunyai kualitas dan karakteristik tertentu yang ditetapkan oleh peneliti untuk dipelajari dan kemudian ditarik kesimpulan.”
Menurut Sugiyono (2010) "Sampel adalah bagian dari jumlah dan karakteristik yang dimiliki oleh populasi tersebut".

Dengan adanya pelayanan aplikasi GO-CAR dapat membantu masyarakat jika ingin menuju ke lokasi yang mengharuskan melewati jalan tol dan pada saat hujan jika ingin berpergian ke suatu tempat. Akan tetapi, masyarakat mengalami sedikit kesulitan untuk memesan jasa GO-CAR apabila terjadi hujan. Dikarenakan mayoritas pengemudi tidak mengambil pemesanan GO-CAR dengan alasan banjir yang mengakibatkan jalanan menjadi macet dan jumlah armada GO-CAR yang disediakan masih sedikit.

Oleh sebab itu, harus ditingkatkan lagi pelayanan terhadap masyarakat untuk meningkatkan kepuasan konsumen dengan cara memberlakukannya sanksi tegas terhadap oknum pengemudi yang mengecewakan konsumen dengan cara membatalkan pemesanan pada saat diterima. Sebelum menjadi pengemudi GO-CAR pihak GO-JEK harus memberikan training yang berkelanjutan tidak hanya sekali saja untuk meningkatkan kesadaran dalam memberikan pelayanan yang terbaik bagi konsumen.

\section{METODELOGI PENELITIAN}

Dalam rangka pengumpulan data yang diperlukan dalam penulisan skripsi penulis menggunakan beberapa metode, yaitu: Hasil dan Pembahasan

Langkah-langkah yang perlu dilakukan pada metode Servqual adalah sebagai berikut:

1. Studi Lapangan

Melakukan pencarian sumber data kepada pihakpihak yang berkompeten untuk mengisi kuesioner.

2. Studi Pustaka

Dengan metode studi pustaka ini, penulis mendapatkan data lain dari buku yang didapatkan dari perpustakaan nasional, perpustakaan STMIK Nusa Mandiri dan beberapa jurnal yang penulis unduh dari internet yang memiliki ISSN dan Volume yang resmi.

3. Identifikasi Masalah

Berisi identifikasi tentang masalah apa saja yang akan dibahas untuk mengetahui seberapa besar kepuasan pelayanan yang telah diberikan oleh pihak GO-CAR kepada konsumen untuk meningkatkan pelayanan yang maksimal.

4. Rumusan Masalah

Membahas tentang masalah apa saja yang akan dijadikan sebagai bahan pokok pembahasan yang berkaitan dengan obyek penelitian. Kemudian akan dilakukan pemikiran yang mendalam untuk menentukan metode apa saja yang akan digunakan untuk memecahkan masalah dalam penelitian. 
5. Tujuan Masalah

Tujuan masalah adalah untuk mengetahui seberapa besar kepuasan pelayanan yang diberikan oleh pihak GO-CAR. Peneliti akan berusaha untuk memberikan usulan apa saja yang dapat dilakukan untuk meningkatkan kualitas pelayanan GO-CAR.

6. Studi Literatur

Tahapan ini adalah melakukan pengumpulan bahan literatur dan informasi berkaitan dengan judul penelitian.

7. Pengumpulan Data

Menyebarkan kuesioner kepada responden. Hal ini dilakukan bersamaan dengan studi lapangan untuk menghemat waktu, biaya, dan tenaga.

8. Uji Validitas dan Reliabilitas

Tahap ini dilakukan untuk menentukan valid dan reliabel atau tidaknya suatu data. Karena jika data tidak valid dan reliabel, maka hasil penelitian tidak akan akurat.

a. Uji Validitas

Validitas didefinisikan sejauh mana ketepatan dan kecermatan suatu instrumen pengukur (test) dalam melakukan fungsi ukurnya. Apabila data tidak valid, maka perlu ditinjau ulang pada penyusunan kuesionernya.

Validitas dihitung dengan rumus korelasi pearson product moment:

$\mathrm{r}$ hitung $=$

$$
\frac{n \cdot\left(\sum X Y\right)-\left(\sum X\right) \cdot\left(\sum Y\right)}{\sqrt{\left[n \cdot \sum X^{2}-(\Sigma X)^{2}\right] \cdot\left[n \cdot \sum Y^{2}-\left(\sum Y\right)^{2}\right]}}
$$

Sumber: Suparman (2015)

Dimana :

$\mathrm{R}=$ Korelasi

$\mathrm{X}=$ Skor setiap item

$\mathrm{Y}=$ Skor total dikurangi skor setiap item tersebut

$\mathrm{N}$ = Ukuran sampel

b. Uji Reliabilitas (Kehandalan)

Pengujian reliabilitas dilakukan untuk menunjukkan sejauh mana kestabilan dan konsistensi instrumen dalam mengukur konsep, selain itu pengujian reliabilitas dilakukan untuk membantu menetapkan kesesuaian pengukur. Untuk menguji reliabilitas dalam penelitian ini, penulis menggunakan rumus alpha cronbach, yaitu:

$$
r_{11}=\left[\frac{k}{(k-1)}\right]\left[1-\frac{\sum \sigma_{b}^{2}}{\sigma_{t}^{2}}\right]
$$

Sumber: Suparman (2015)

Dimana:

$\mathrm{r}_{11}=$ reliabilitas kuesioner
$\mathrm{K}=$ Banyaknya jumlah butir pertanyaan

$$
\begin{aligned}
& \sigma_{b}^{2}=\text { Jumlah variansi butir } \\
& \sigma_{t}^{2}=\text { Variansi total }
\end{aligned}
$$

9. Pengolahan Data Metode Servqual

Pengolahan data dilakukan untuk mendapatkan jumlah sampel minimal sudah mencukupi atau belum. Jika belum cukup,maka kembali ke tahap penyebaran kuesioner.

10. Hasil Dan Pembahasan

Tahap selanjutnya adalah data yang valid dan reliabel akan dianalisis ke tahap yang lebih mendalam guna mendapatkan hasil yang akurat dan sesuai dengan keadaan aslinya.

11. Kesimpulan Dan Saran Langkah akhir dari penelitian ini adalah untuk menarik kesimpulan berdasarkan hasil pengolahan dan analisis data, serta memberikan saran-saran yang dapat dijadikan acuan kepada pihak GO-CAR maupun pihak lain yang membutuhkan.

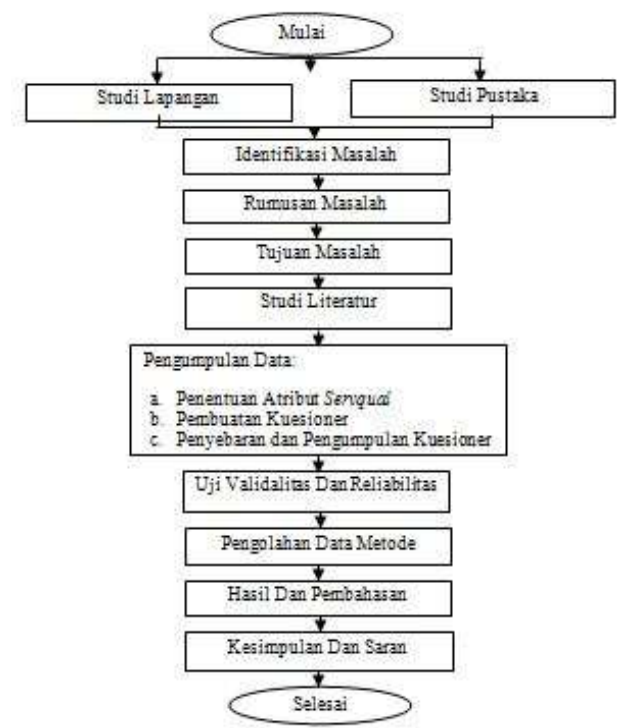

Sumber: Skema Tahapan Penelitian

Gambar 1. Tahapan Penelitian

A. Responden Persepsi

Tabel 1. Usia Responden Persepsi dan Harapan

\begin{tabular}{|c|c|c|}
\hline Usia & Jumlah responden & Persentase \\
\hline$<23$ tahun & 78 & $84 \%$ \\
\hline$>23$ tahun & 15 & $16 \%$ \\
\hline Total & 93 & $100 \%$ \\
\hline
\end{tabular}

Sumber : Olahan data (2017)

Tabel 2. Lokasi Responden Persepsi dan Harapan 


\begin{tabular}{|c|c|c|}
\hline Lokasi & Jumlah responden & Persentase \\
\hline Jakarta & 72 & $77 \%$ \\
\hline Luar Jakarta & 21 & $23 \%$ \\
\hline Total & 93 & $100 \%$ \\
\hline
\end{tabular}

Sumber : Olahan data (2017)

Tabel 3. Pembantu Uji Validitas Pertanyaan X1

\begin{tabular}{|c|c|c|c|c|c|}
\hline$k(x 1)$ & $x$ & $y$ & xy & $x^{2}$ & $y^{2}$ \\
\hline 1 & 5 & 67 & 335 & 25 & 4489 \\
\hline 2 & 4 & 63 & 252 & 16 & 3969 \\
\hline 3 & 4 & 63 & 252 & 16 & 3969 \\
\hline 4 & 4 & 65 & 260 & 16 & 4225 \\
\hline 5 & 3 & 51 & 153 & 9 & 2601 \\
\hline 6 & 4 & 60 & 240 & 16 & 3600 \\
\hline 7 & 3 & 51 & 153 & 9 & 2601 \\
\hline 8 & 3 & 62 & 186 & 9 & 3844 \\
\hline 9 & 3 & 52 & 156 & 9 & 2704 \\
\hline 10 & 4 & 63 & 252 & 16 & 3969 \\
\hline 11 & 5 & 80 & 400 & 25 & 6400 \\
\hline 12 & 4 & 60 & 240 & 16 & 3600 \\
\hline 13 & 4 & 64 & 256 & 16 & 4096 \\
\hline 14 & 4 & 54 & 216 & 16 & 2916 \\
\hline 15 & 5 & 77 & 385 & 25 & 5929 \\
\hline 16 & 4 & 59 & 236 & 16 & 3481 \\
\hline 17 & 4 & 64 & 256 & 16 & 4096 \\
\hline 18 & 5 & 63 & 315 & 25 & 3969 \\
\hline 19 & 3 & 52 & 156 & 9 & 2704 \\
\hline 20 & 5 & 68 & 340 & 25 & 4624 \\
\hline 21 & 4 & 75 & 300 & 16 & 5625 \\
\hline 22 & 3 & 63 & 189 & 9 & 3969 \\
\hline 23 & 4 & 74 & 296 & 16 & 5476 \\
\hline 24 & 4 & 54 & 216 & 16 & 2916 \\
\hline 25 & 4 & 63 & 252 & 16 & 3969 \\
\hline 26 & 4 & 60 & 240 & 16 & 3600 \\
\hline 27 & 4 & 64 & 256 & 16 & 4096 \\
\hline 28 & 4 & 61 & 244 & 16 & 3721 \\
\hline 29 & 4 & 65 & 260 & 16 & 4225 \\
\hline 30 & 3 & 49 & 147 & 9 & 2401 \\
\hline 31 & 4 & 51 & 204 & 16 & 2601 \\
\hline 32 & 5 & 63 & 315 & 25 & 3969 \\
\hline 33 & 4 & 64 & 256 & 16 & 4096 \\
\hline 34 & 4 & 48 & 192 & 16 & 2304 \\
\hline 35 & 3 & 53 & 159 & 9 & 2809 \\
\hline 36 & 5 & 68 & 340 & 25 & 4624 \\
\hline 37 & 5 & 79 & 395 & 25 & 6241 \\
\hline 38 & 4 & 65 & 260 & 16 & 4225 \\
\hline 39 & 3 & 56 & 168 & 9 & 3136 \\
\hline 40 & 4 & 51 & 204 & 16 & 2601 \\
\hline 41 & 5 & 80 & 400 & 25 & 6400 \\
\hline 42 & 5 & 68 & 340 & 25 & 4624 \\
\hline 43 & 5 & 79 & 395 & 25 & 6241 \\
\hline 44 & 4 & 67 & 268 & 16 & 4489 \\
\hline 45 & 4 & 60 & 240 & 16 & 3600 \\
\hline 46 & 4 & 68 & 272 & 16 & 4624 \\
\hline 47 & 4 & 63 & 252 & 16 & 3969 \\
\hline 48 & 3 & 59 & 177 & 9 & 3481 \\
\hline
\end{tabular}

Sumber : Olahan data (2017)

Berdasarkan tabel 4. uji validitas pertanyaan X1 dalam penelitian ini menggunakan korelasi Pearson Product Moment (koefesien korelasi skor item pertanyaan dengan nilai total), jumlah data yang diolah 93 data masing-masing untuk gap,sebagai pembandingnya tabel yang dapat digunakan adalah tabel $\mathrm{r}$ Pearson Product Moment, dalam perhitungan ini mendapatkan hasil sebagai berikut :

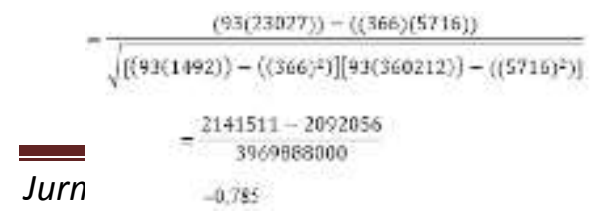

uter / Vol. 5, No. 1, Maret 2019
Tabel 4. Hasil dari Uji Validitas Persepsi Keseluruhan

\begin{tabular}{|c|c|c|c|}
\hline $\begin{array}{c}\text { Variabel } \\
\text { Pernyataan }\end{array}$ & r Hitung & r Tabel & Hasil \\
\hline $\mathrm{x} 1$ & 0,785 & 0,202 & Valid \\
\hline $\mathrm{x} 2$ & 0,694 & 0,202 & Valid \\
\hline $\mathrm{x} 3$ & 0,738 & 0,202 & Valid \\
\hline $\mathrm{x} 4$ & 0,819 & 0,202 & Valid \\
\hline $\mathrm{x} 5$ & 0,730 & 0,202 & Valid \\
\hline $\mathrm{x} 6$ & 0,851 & 0,202 & Valid \\
\hline $\mathrm{x} 7$ & 0,837 & 0,202 & Valid \\
\hline $\mathrm{x} 8$ & 0,670 & 0,202 & Valid \\
\hline $\mathrm{x} 9$ & 0,785 & 0,202 & Valid \\
\hline $\mathrm{x} 10$ & 0,744 & 0,202 & Valid \\
\hline $\mathrm{x} 11$ & 0,818 & 0,202 & Valid \\
\hline $\mathrm{x} 12$ & 0,761 & 0,202 & Valid \\
\hline $\mathrm{x} 13$ & 0,728 & 0,202 & Valid \\
\hline $\mathrm{x} 14$ & 0,744 & 0,202 & Valid \\
\hline $\mathrm{x} 15$ & 0,885 & 0,202 & Valid \\
\hline $\mathrm{x} 16$ & 0,887 & 0,202 & Valid \\
\hline
\end{tabular}

Sumber: Data Olahan (2017)

Berikut adalah bentuk perhitungan manual untuk mencari nilai validitas persepsi untuk setiap pertanyaan:

1. Uji Reliabilitas Pertanyaan X1

$$
\begin{aligned}
& \sigma_{\hat{b}}-\frac{(\pi, \cdots)-\frac{\pi+n}{n}}{n}
\end{aligned}
$$

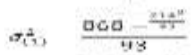

$$
\begin{aligned}
& n_{i 2}-\frac{\operatorname{Aris}-40,2,4,301}{23} \\
& \theta(2)-\begin{array}{c}
515.500 y \\
9 a
\end{array}
\end{aligned}
$$

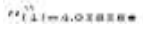

Rumus untuk menentukan varian total persepsi:

$$
\begin{aligned}
\sigma_{t}^{2} & =\frac{\sum x^{2}-\frac{(\Sigma x)^{2}}{n}}{n} \\
\sigma_{t}^{2} & =\frac{22906-\frac{(5716)^{2}}{98}}{93} \\
\sigma_{t}^{2} & =\frac{22906-351318,8817}{93} \\
\sigma_{t}^{2} & =\frac{328412,8817}{93}
\end{aligned}
$$

Untuk melakuķ̧an 35 pengujian reliabilitas yang dilakukan. Peneliti menggunakan koefisien alpha cronbach's. Sedangkan untuk membantu mencari hasil dari perhitungan uji reliabilitas, peneliti 
menggunakan Microsoft excel 2010 yang dapat dilihat selengkapnya pada lampiran. Untuk hasil uji kuesioner pada perhitungan reliabilitas dapat di lihat dibawah ini.

Rumus untuk menghitung nilai reliabilitas persepsi:

$$
\begin{aligned}
& \mathrm{r} 11=\left[\frac{k}{k-1}\right]\left[1-\frac{\Sigma \sigma_{b}^{2}}{\sigma_{t}^{2}}\right] \\
& \mathrm{r} 11=\left[\frac{16}{16-1}\right]\left[1-\frac{62,92196}{3531,321}\right] \\
& \mathrm{r} 11=1,066667 \times 0,982182 \\
& \mathrm{r} 11=1,047661
\end{aligned}
$$

2. Perhitungan pembobotan dan rata-rata jawaban kuesioner persepsi kepuasan pengguna aplikasi GO-CAR.Perhitungan pembobotan untuk tingkat kinerja/persepsi konsumen sebagai berikut ini :

1. Variabel pertanyaan 1

$$
\begin{aligned}
& =(5 \times 19)+(4 \times 52)+(3 \times 20)+(2 \times 1)+(1 \times 1) \\
& =95+208+60+2+1 \\
& =366
\end{aligned}
$$

Rata-rata jawaban responden dihitung dengan persamaan berikut:

1. Menghitung rata-rata nilai kinerja atau persepsi untuk setiap variabel:

$\overline{\mathrm{y}}=\frac{\mathrm{ayi}}{\mathrm{n}}$

Keterangan:

$\bar{y}=$ Nilai rata-rata Kinerja atau Persepsi pelanggan

$\Sigma y i=$ jumlah bobot jawaban responden

$n=$ jumlah responden

a. Variabel 1

Bobot untuk frekuensi jawaban variabel $1=$

\begin{tabular}{|c|c|c|c|c|c|}
\hline$k(x 1)$ & $\mathrm{x}$ & $\mathrm{y}$ & $\mathrm{xy}$ & $\mathrm{x}^{2}$ & $y^{2}$ \\
\hline 1 & 5 & 80 & 400 & 25 & 6400 \\
\hline 2 & 5 & 67 & 335 & 25 & 4489 \\
\hline 3 & 5 & 67 & 335 & 25 & 4489 \\
\hline 4 & 5 & 70 & 350 & 25 & 4900 \\
\hline 5 & 5 & 80 & 400 & 25 & 6400 \\
\hline 6 & 5 & 66 & 330 & 25 & 4356 \\
\hline 7 & 5 & 80 & 400 & 25 & 6400 \\
\hline 8 & 5 & 80 & 400 & 25 & 6400 \\
\hline 9 & 5 & 80 & 400 & 25 & 6400 \\
\hline 10 & 5 & 80 & 400 & 25 & 6400 \\
\hline 11 & 5 & 80 & 400 & 25 & 6400 \\
\hline 12 & 5 & 58 & 290 & 25 & 3364 \\
\hline 13 & 5 & 68 & 340 & 25 & 4624 \\
\hline 14 & 5 & 80 & 400 & 25 & 6400 \\
\hline 15 & 5 & 80 & 400 & 25 & 6400 \\
\hline 16 & 5 & 80 & 400 & 25 & 6400 \\
\hline 17 & 5 & 80 & 400 & 25 & 6400 \\
\hline 18 & 5 & 65 & 325 & 25 & 4225 \\
\hline 19 & 5 & 80 & 400 & 25 & 6400 \\
\hline 20 & 5 & 80 & 400 & 25 & 6400 \\
\hline 21 & 5 & 80 & 400 & 25 & 6400 \\
\hline 22 & 5 & 80 & 400 & 25 & 6400 \\
\hline 23 & 5 & 80 & 400 & 25 & 6400 \\
\hline 24 & 5 & 74 & 370 & 25 & 5476 \\
\hline 25 & 5 & 80 & 400 & 25 & 6400 \\
\hline 26 & 4 & 64 & 256 & 16 & 4096 \\
\hline 27 & 5 & 68 & 340 & 25 & 4624 \\
\hline 28 & 5 & 68 & 340 & 25 & 4624 \\
\hline 29 & 5 & 78 & 390 & 25 & 6084 \\
\hline 30 & 5 & 69 & 345 & 25 & 4761 \\
\hline 31 & 5 & 66 & 330 & 25 & 4356 \\
\hline 32 & 4 & 64 & 256 & 16 & 4096 \\
\hline 33 & 4 & 63 & 252 & 16 & 3969 \\
\hline 34 & 5 & 71 & 355 & 25 & 5041 \\
\hline 35 & 5 & 66 & 330 & 25 & 4356 \\
\hline 36 & 5 & 72 & 360 & 25 & 5184 \\
\hline 37 & 5 & 69 & 345 & 25 & 4761 \\
\hline 38 & 5 & 78 & 390 & 25 & 6084 \\
\hline
\end{tabular}
366

Jumlah responden $=93$

$\overline{\mathrm{y}}=\frac{366}{93}$

$\overline{\mathrm{y}}=3,93$

Tabel 5. Pembantu Uji Validitas Harapan Pertanyaan X1

\begin{tabular}{|l|l|l|l|l|l|}
39 & 5 & 71 & 355 & 25 & 5041 \\
\hline 40 & 5 & 70 & 350 & 25 & 4900 \\
\hline 41 & 5 & 80 & 400 & 25 & 6400 \\
\hline 42 & 5 & 71 & 355 & 25 & 5041 \\
\hline 43 & 5 & 71 & 355 & 25 & 5041 \\
\hline 44 & 5 & 73 & 365 & 25 & 5329 \\
\hline 45 & 5 & 68 & 340 & 25 & 4624 \\
\hline 46 & 5 & 70 & 350 & 25 & 4900 \\
\hline 47 & 5 & 69 & 345 & 25 & 4761 \\
\hline 48 & 5 & 66 & 330 & 25 & 4356 \\
\hline 49 & 5 & 73 & 365 & 25 & 5329 \\
\hline 50 & 5 & 70 & 350 & 25 & 4900 \\
\hline
\end{tabular}




\begin{tabular}{|c|c|c|c|c|c|}
\hline 51 & 4 & 70 & 280 & 16 & 4900 \\
\hline 52 & 5 & 73 & 365 & 25 & 5329 \\
\hline 53 & 4 & 72 & 288 & 16 & 5184 \\
\hline 54 & 5 & 70 & 350 & 25 & 4900 \\
\hline 55 & 5 & 79 & 395 & 25 & 6241 \\
\hline 56 & 5 & 71 & 355 & 25 & 5041 \\
\hline 57 & 4 & 59 & 236 & 16 & 3481 \\
\hline 58 & 5 & 71 & 355 & 25 & 5041 \\
\hline 59 & 5 & 68 & 340 & 25 & 4624 \\
\hline 60 & 4 & 66 & 264 & 16 & 4356 \\
\hline 61 & 5 & 71 & 355 & 25 & 5041 \\
\hline 62 & 4 & 68 & 272 & 16 & 4624 \\
\hline 63 & 5 & 67 & 335 & 25 & 4489 \\
\hline 64 & 5 & 80 & 400 & 25 & 6400 \\
\hline 65 & 5 & 68 & 340 & 25 & 4624 \\
\hline 66 & 4 & 67 & 268 & 16 & 4489 \\
\hline 67 & 5 & 67 & 335 & 25 & 4489 \\
\hline 68 & 5 & 68 & 340 & 25 & 4624 \\
\hline 69 & 5 & 68 & 340 & 25 & 4624 \\
\hline 70 & 5 & 75 & 375 & 25 & 5625 \\
\hline 71 & 5 & 80 & 400 & 25 & 6400 \\
\hline 72 & 4 & 65 & 260 & 16 & 4225 \\
\hline 73 & 5 & 74 & 370 & 25 & 5476 \\
\hline 74 & 5 & 67 & 335 & 25 & 4489 \\
\hline 75 & 5 & 69 & 345 & 25 & 4761 \\
\hline 76 & 5 & 75 & 375 & 25 & 5625 \\
\hline 77 & 5 & 73 & 365 & 25 & 5329 \\
\hline 78 & 5 & 73 & 365 & 25 & 5329 \\
\hline 79 & 4 & 74 & 296 & 16 & 5476 \\
\hline 80 & 5 & 75 & 375 & 25 & 5625 \\
\hline 81 & 5 & 74 & 370 & 25 & 5476 \\
\hline 82 & 4 & 75 & 300 & 16 & 5625 \\
\hline 83 & 4 & 75 & 300 & 16 & 5625 \\
\hline 84 & 5 & 72 & 360 & 25 & 5184 \\
\hline 85 & 5 & 72 & 360 & 25 & 5184 \\
\hline 86 & 5 & 73 & 365 & 25 & 5329 \\
\hline 87 & 4 & 73 & 292 & 16 & 5329 \\
\hline 88 & 5 & 74 & 370 & 25 & 5476 \\
\hline 89 & 5 & 73 & 365 & 25 & 5329 \\
\hline 90 & 5 & 72 & 360 & 25 & 5184 \\
\hline 91 & 4 & 73 & 292 & 16 & 5329 \\
\hline 92 & 5 & 77 & 385 & 25 & 5929 \\
\hline 93 & 5 & 77 & 385 & 25 & 5929 \\
\hline TOTAI & 450 & 6726 & 32602 & 2190 & 489170 \\
\hline
\end{tabular}

Sumber: Olahan Data (2017)

Berdasarkan tabel 6. uji validitas pertanyaan X1 dalam penelitian ini menggunakan korelasi Pearson Product Moment (koefesien korelasi skor item pertanyaan dengan nilai total), jumlah data yang diolah 93 data masing-masing untuk gap,sebagai pembandingnya tabel yang dapat digunakan adalah tabel $r$ Pearson Product Moment, dalam perhitungan ini mendapatkan hasil sebagai berikut :

\section{Tabel 6. Hasil dari Uji Validitas Harapan} Keseluruhan

\begin{tabular}{|c|c|c|c|}
\hline $\begin{array}{c}\text { Variabel } \\
\text { Pernyataan }\end{array}$ & $\begin{array}{c}\mathbf{r} \\
\text { Hitung }\end{array}$ & $\begin{array}{c}\mathbf{r} \\
\text { Tabel }\end{array}$ & Hasil \\
\hline $\mathbf{x} 1$ & 0,307 & 0,202 & Valid \\
\hline $\mathbf{x} 2$ & 0,440 & 0,202 & Valid \\
\hline $\mathbf{x} 3$ & 0,435 & 0,202 & Valid \\
\hline $\mathbf{x} 4$ & 0,564 & 0,202 & Valid \\
\hline $\mathbf{x} 5$ & 0,428 & 0,202 & Valid \\
\hline $\mathbf{x} 6$ & 0,717 & 0,202 & Valid \\
\hline $\mathbf{x} 7$ & 0,753 & 0,202 & Valid \\
\hline $\mathbf{x} 8$ & 0,345 & 0,202 & Valid \\
\hline $\mathbf{x} 9$ & 0,777 & 0,202 & Valid \\
\hline $\mathbf{x} 10$ & 0,685 & 0,202 & Valid \\
\hline $\mathbf{x} 11$ & 0,672 & 0,202 & Valid \\
\hline $\mathbf{x} 12$ & 0,722 & 0,202 & Valid \\
\hline $\mathbf{x} 13$ & 0,655 & 0,202 & Valid \\
\hline $\mathbf{x} 14$ & 0,501 & 0,202 & Valid \\
\hline $\mathbf{x} 15$ & 0,698 & 0,202 & Valid \\
\hline $\mathbf{x} 16$ & 0,702 & 0,202 & Valid \\
\hline
\end{tabular}

Sumber: Data Olahan (2017)

Berikut adalah bentuk perhitungan manual untuk mencari nilai validitas harapan untuk setiap pertanyaan:

1. Uji Reliabilitas Pertanyaan X1

$$
\begin{aligned}
& \sigma_{b}^{2}=\frac{\left(\Sigma x^{2}\right)-\frac{(\Sigma x)^{2}}{n}}{n} \\
& \sigma_{(1)}^{2}=\frac{2190-\frac{450^{2}}{93}}{93} \\
& \sigma_{(1)}^{2}=\frac{2190-2177,419}{93} \\
& \sigma_{(1)}^{2}=\frac{12,58065}{93} \\
& \sigma_{(1)}^{2}=0,135276
\end{aligned}
$$

Rumus untuk menentukan nilai varian total harapan:

$$
\begin{gathered}
=\frac{(93(32602))-((450)(6726))}{\sqrt{\left.\left[(93(2190))-\left((450)^{2}\right)\right][93(489170))-\left((6726)^{2}\right)\right]}} \\
=\frac{3031986-3026700}{296868780} \\
=0,307
\end{gathered}
$$




$$
\begin{aligned}
& \sigma_{t}^{2}=\frac{\sum x^{2}-\frac{\left(\sum x\right)^{2}}{n}}{n} \\
& \sigma_{t}^{2}=\frac{30914-\frac{(6726)^{2}}{98}}{93} \\
& \sigma_{t}^{2}=\frac{30914-486441,7}{93} \\
& \sigma_{t}^{2}=\frac{455527,7}{93} \\
& \sigma_{t}^{2}=4898,147
\end{aligned}
$$

Untuk melakukan pengujian reliabilitas yang dilakukan. Peneliti menggunakan koefisien alpha cronbach. Sedangkan untuk membantu mencari hasil dari perhitungan uji reliabilitas, peneliti menggunakan Microsoft excel 2010 yang dapat dilihat selengkapnya pada lampiran. Untuk hasil uji kuesioner pada perhitungan reliabilitas dapat di lihat dibawah ini:

Rumus untuk menghitung nilai reliabilitas harapan

$\mathrm{r} 11=\left[\frac{k}{k-1}\right]\left[1-\frac{\Sigma \sigma_{k}^{2}}{\sigma_{t}^{2}}\right]$

$\mathrm{r} 11=\left[\frac{16}{16-1}\right]\left[1-\frac{5,122211}{4898,147}\right]$

$\mathrm{r} 11=1,066667 \times 0,998954$

$\mathrm{r} 11=1,065551$

5. Perhitungan pembobotan dan rata-rata jawaban kuesioner harapan kepuasan pengguna aplikasi GO-CAR

1. Variabel pertanyaan 1

$=(5 \times 78)+(4 \times 15)+(3 \times 0)+(2 \times 0)+$

( $1 \times 0)$

$=390+60+0+0+0$

Rata-rata jawaban responden dihitung dengan persamaan berikut:

1. Menghitung rata-rata nilai harapan atau ekspetasi untuk setiap variabel:

$\overline{\mathrm{y}}=\frac{\mathrm{Byi}}{\mathrm{n}}$

Keterangan:

$\bar{y}=$ Nilai rata-rata harapan atau ekspetasi pelanggan

$\Sigma y i=$ jumlah bobot jawaban responden

$n=$ jumlah responden

a. Variabel 1

Bobot untuk frekuensi jawaban variabel $1=$ 450
Jumlah responden $=93$

$$
\begin{aligned}
& \bar{y}=\frac{450}{9 a} \\
& \bar{y}=4,83
\end{aligned}
$$

6. Perhitungan Nilai Gap Servqual score (S) untuk setiap variabel

Perhitungan nilai gap dari kinerja / persepsi dan harapan dilakukan dengan rumus:

$$
\mathrm{SQ}=\bar{y}-\bar{x}
$$

Keterangan:

$\mathrm{SQ}=$ Nilai gap

$\bar{y}=$ Nilai rata-rata Kinerja atau persepsi pelanggan

\begin{tabular}{|c|c|c|c|c|c|}
\hline $\begin{array}{l}\text { Dimensi } \\
\text { Variabel }\end{array}$ & $\begin{array}{c}\text { Variab } \\
\text { el } \\
\text { Pernya } \\
\text { taan }\end{array}$ & $\begin{array}{l}\text { Nilai } \\
\text { Rata- } \\
\text { rata } \\
\text { Persep } \\
\text { si } \\
\end{array}$ & $\begin{array}{c}\text { Nilai } \\
\text { Rata- } \\
\text { rata } \\
\text { Harap } \\
\text { an } \\
\end{array}$ & $\begin{array}{l}\text { Nilai } \\
\text { GAP }\end{array}$ & $\begin{array}{l}\mathrm{R} \\
\mathrm{A} \\
\mathrm{N} \\
\mathrm{K}\end{array}$ \\
\hline \multirow{3}{*}{$\begin{array}{c}\text { Responsi } \\
\text { veness }\end{array}$} & $\mathrm{x} 1$ & 3,94 & 4,84 & $-0,9$ & 15 \\
\hline & $\mathrm{x} 2$ & 3,57 & 4,66 & $-1,09$ & 16 \\
\hline & $\mathrm{x} 3$ & 4,02 & 4,69 & $-0,67$ & 11 \\
\hline \multirow{3}{*}{$\begin{array}{c}\text { Reliabilit } \\
y\end{array}$} & $\mathrm{x} 4$ & 3,91 & 4,52 & $-0,61$ & 6 \\
\hline & $\mathrm{x} 5$ & 4 & 4,55 & $-0,55$ & 3 \\
\hline & $x 6$ & 3,78 & 4,38 & $-0,6$ & 5 \\
\hline \multirow{3}{*}{$\begin{array}{c}\text { Assuranc } \\
\mathrm{e}\end{array}$} & $\mathrm{x} 7$ & 3,83 & 4,44 & $-0,61$ & 7 \\
\hline & $\mathrm{x} 8$ & 4,06 & 4,73 & $-0,67$ & 11 \\
\hline & $\mathrm{x} 9$ & 3,51 & 4,30 & $-0,79$ & 13 \\
\hline \multirow{2}{*}{ Emphaty } & $\mathrm{x} 10$ & 3,99 & 4,52 & $-0,53$ & 1 \\
\hline & $\mathrm{x} 11$ & 3,88 & 4,54 & $-0,66$ & 10 \\
\hline \multirow{3}{*}{$\begin{array}{c}\text { Tangible } \\
\text { s }\end{array}$} & $\mathrm{x} 12$ & 3,69 & 4,27 & $-0,58$ & 4 \\
\hline & $\mathrm{x} 13$ & 3,81 & 4,45 & $-0,64$ & 9 \\
\hline & $\mathrm{x} 14$ & 3,82 & 4,63 & $-0,81$ & 14 \\
\hline \multirow{2}{*}{$\begin{array}{c}\text { Custome } \\
\text { r } \\
\text { Satisfacti } \\
\text { on }\end{array}$} & $\mathrm{x} 15$ & 3,75 & 4,38 & $-0,63$ & 8 \\
\hline & x16 & 3,90 & 4,44 & $-0,54$ & 2 \\
\hline
\end{tabular}
$\bar{x}=$ Nilai rata-rata harapan atau ekspetasi pelanggan

Hasil dari perhitungan rata-rata dan nilai gap yaitu:

Tabel 7. Hasil nilai rata-rata persepsi dan harapan jawaban responden per dimensi, nilai gap, dan rank

Sumber : Data Olahan (2017)

\section{Kualitas Pelayanan GAP}




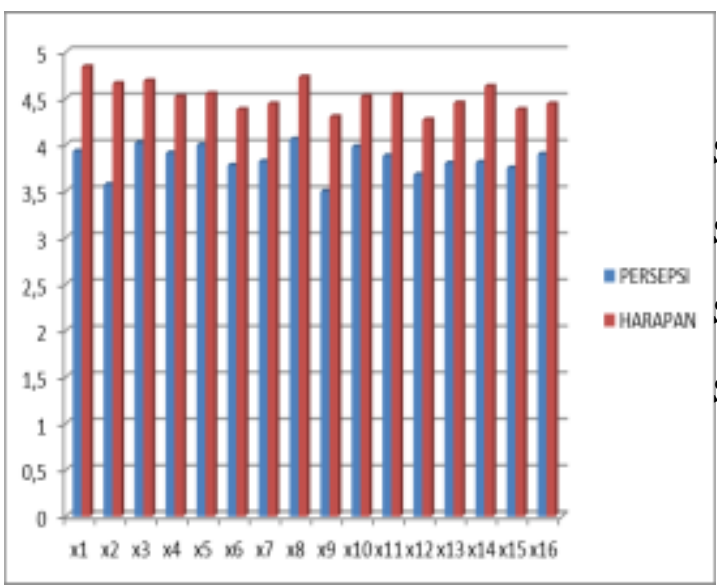

Sumber : Data Olahan (2017)

Gambar 2. Grafik Perbandigan Antara Nilai Kinerja atau Persepsi Dan Nilai Harapan atau Ekspetasi

Berdasarkan hasil dari tabel dan grafik yang ada diatas, diperoleh kesimpulan bahwa nilai harapan atau ekspetasi lebih besar dibandingkan nilai kinerja atau persepsi.

\section{DAFTAR PUSTAKA}

Bahri, Syamsul dan Fahkry Zamzam. (2014). Model Penelitian Kuantitatif Berbasis Sem-Amos.

Yogyakarta: Deepublish.

Kaihatu, Stafanus, Thomas. (2008). Analisa Kesenjangan Kualitas Pelayanan dan Kepuasan Konsumen Pengunjung Plaza Tanjung Surabaya. Jurnal Ekonomi Manajemen. Vol.10, No. 1, Maret 2008. Diambil dari: http://jurnalmanajemen.petra.ac.id/index.php/man/ article/view/16793. (13 April 2017)

Kusumadewi, Sri dan Hari Purnomo. (2013). Aplikasi Logika Fuzzy Untuk Pendukung Keputusan. Yogyakarta: Graha Ilmu.

Pramono, Djoko. (2011). Analisa Data Profesional dengan Excel 2010. Jakarta: PT Elex Media Komputindo.

Resihono, Dwi, Legowo. Analisis Pengaruh Kualitas Jasa Pelayanan Terhadap Tingkat Kepuasan Konsumen Pada Hotel Kusuma Kartika Sari. Politek Nosains Vol.X, No. 1, Maret 2011. Diambil dari: http://www.ejournal.politama.ac.id/index.php/poli teknosains/article/view/32. (13 april 2017)

Sangadji, Etta Mamang dan Sopiah. (2010). Metodologi Penelitian. Yogyakarta: CV Andi Offset.

Sikumbang, Erna Delima. (2017). Analisa Tingkat Kepuasan Pelanggan Dengan Metode Fuzzy Servqual. ISSN: 2442-2436 Vol. III No. 1,
Februari

2017.

Diambil

dari:http://ejournal.bsi.ac.id/ejurnal/index.php/jtk/ article/view/1341. (13 April 2017)

Sugiyono. (2010). Metode Penelitian Pendidikan. Bandung: Alfabeta.

Sugiyono. (2014). Metode Penelitian Administrasi. Bandung: Alfabeta.

Sujarweni, V. Wiratna. (2015). SPSS Untuk Penelitian. Yogyakarta: Pustaka Baru Press.

Suparman dan Sakuri Dahlan. (2015). Analisis Kepuasan Pelanggan Dengan Metod Servqual Pada PDAM Tirta Wijaya Cilacap. Intuisi Tenologi Dan Seni. ISSN : 1978-2497, November 2015. Diambil dari:http://ejournal.sttwiworotomo.ac.id/index.php /iteks/article/view/122. (16 April 2017)

\section{PROFIL PENULIS}

Nandang Iriadi,Lahir di Jakarta 10 Oktober 1977 sebagi Staf Akademik,Mengajar Di Fakultas Teknologi Informasi UBSI Jakarta. Aktif Mengikuti Seminar, dan menulis Paper dibeberapa Jurnal,Diantaranya:Paradigma,Jurnal speed,Jurnal Teknologi Informatika \& Komputer UMHT,Pernah mengikuti Semiar Internasional.

Priatno, Lahir di Jakarta, 26 Juni 1975 sebagai Staf Akademik mengajar di Jurusan Manajemen Informatika pada AMIK BSI Jakarta. Karya tulisan: Penggunaan Metode Pemrograman Berorientasi Objek (Object Oriented Programming) Pada Bahasa Pemrograman (Paradigma Vol IX No. 2 April 2008, ISSN 14105963), Analysis of The Master Plan IT at PT Sari Melati Kencana Jakarta (Proceedings International Seminar on Scientific Issues and Trends, 22 Oktober 2011(LPPM BSI ISBN 978602-99213-1-1), Analisis Implementasi Teknologi Informasi Bisnis Dalam Peningkatan Kinerja Perusahaan Study Kasus : PT. ACA (ANTA CITRA ARGES) Jakarta, (Proceedings, Seminar Nasional Informasi dan Teknologi, 13 Juni 2012 (LPPM BSI ISBN 978-602-99213-2-8), Analisis Pengaruh Pendekatan Personal Tenaga Penjual, Kualitas Produk, Dan Harga Terhadap Kepuasan Pelanggan, Jurnal Pilar 2 (X), 143-148 Vol. 2014, Penerimaan Buku Sekolah Elektronik (Bse) Pada SMA di Jakarta Menggunakan Pendekatan Technology In Acceptance Model Jurnal Informatika Dan Bisnis 2, 1-8 Vol., 2016, Analisa Penerimaan Teknologi Informasi Terhadap Prestasi Anak Menggunakan Metode Technology Acceptance Model, Konferensi Nasional Ilmu Sosial \& Teknologi (KNIST) Vol. 2017, Sistem Informasi Penjualan Air Minum 
Bonanza Menggunakan Java Netbeans 7.0.1 Pada PT. Mejisinar Kasih Jakarta, Speed - Sentra Penelitian Engineering Dan Edukasi 10, 2026 Vol. , 2018

Mohammad, Ikhsan Saputro, Lahir di Jakarta 14 November 1968sebagi Dosen Tetao Mengajar Di Fakultas Komputer UMHT Jakarta. Aktif Mengikuti Seminar, dan menulis Paper dibeberapa Jurnal, dan sebagia pnggelola dari Jurnal Teknologi Informatika \& Komputer UMHT, Pernah mengikuti Semiar Internasional. 